\title{
Influence of host plants and some leaf contents on biological aspects of Tetranychus urticae Koch (Arachnida: Acari: Tetranychidae)
}

\author{
Malakah F. I. Elsadany
}

\begin{abstract}
Background: Phytophagous mites infest most host plants as vegetable, field crops, and ornamental plants. Tetranychus urticae spend most of its life cycle on plant, especially on leaves, and it causes serious damage. The development periods and reproduction of T. urticae are influenced by characteristics for host plant.

Purpose of the study: To know the effect of host plant on Tetranychus urticae in order to recognize the most suitable hosts for increasing population Tetranychus urticae to be used as food for the mites, as a bio-control agent against different pests.

Results: The results revealed that the hosts affected significantly on incubation period. Significant differences were found among different host plant leaves for longevity, life span periods and average oviposition period of T. urticae under controlled temperature $\left(28.5 \pm 2^{\circ} \mathrm{C}\right)$ and relative humidity $(76 \pm 5 \%)$. Average of the reproduction rate per female was higher when $T$. urticae was reared on leaves of mulberry, while the percentage of hatchability was highest when the females were fed on leaves of mulberry. The sex ratio was higher when it was fed on leaves of castor bean. Nitrogen content in host plant leaves varied, and differences were found between three host plants in concentrations concerning phosphorus, potassium, and total chlorophyll. The correlation between longevity period and nitrogen was highly significantly positive in the case of sweet potato, while the correlation between the duration spider mite life cycle and nitrogen content and the correlation between longevity periods with potassium were significantly positive in castor bean.

Conclusions: Total immature stages and life cycle were shortest when spider mite was fed on mulberry leaves. The greatest values of reproduction rate and hatchability were on mulberry leaves than on other crops and followed by castor bean. Sex ratio of $T$. urticae was highest on castor bean leaves. Developmental and reproduction rate of $T$. urticae are influenced by tissue nutrient content for host plant.
\end{abstract}

Keywords: Biological aspects, Tetranychus urticae, Leaf contents, NPK, Total chlorophyll

Correspondence: malkahelsadany@gmail.com

Acarology of Cotton and Crops Department, Plant Protection Research Institute, Sakha Agricultural Research Station, Kafr El-Sheikh, Agricultural Research Center, Giza, Egypt 


\section{Background}

Two-spotted spider mite, Tetranychus urticae Koch, is one of the most serious agricultural pests in the world, and it causes yield losses in many crops whether ornamental, vegetable, or field crops (Fasulo, 2009). About 140 species of Tetranychus have been described. T. urticae is distinguished by a good lateral mount of the male aedeagus NAPPO (2014), belongs to the super family: Tetranychoidea, which comprise spider mites (Tetranychidae), and can be distinguished from other tetranychoids mostly by their palp in female from which silk filaments were produced. About 88 host plants are infested by T. urticae, including common bean, soybean, cucumber, melons, peanut, sweet potato, castor bean, some palms, banana, and papaya (Bolland, Gutierrez, \& Freshman, 1998; Migeon \& Dorkeld, 2013). Spider mites, strictly phytophagous pests, are on the lower surface of leaves more than upper surface, and this depends on the species and both surfaces may be occupied during high infestations. Feeding on plant cells produces leaf yellowing and bronzing and heavy damaged leaves that become brown on the upper surface. The undersurface of leaves may have a grayish cast due to webbing where there are leaf deformity and tissue death. Two-spotted spider mites can feed on 18 to 22 plant cells per minute (Rinehold, Bell, \& Waiters, 2015). The mites are dispersal, and presence of webbing may indicate the presence of it. Primary role of webbing is to protect eggs, and the colony and these webs could be detected with the naked eye. The nutritional quality of the host plant is one of the most important factors of growth and reproduction for crop pests (Motahari, et al., 2014). The present study aims to study the most preferred host plants to T. urticae and the effect of host plant on T. urticae. These information are important for successful rearing of spider mites. These mites could be used as a prey for predatory, in case mites of studying biological aspects of predatory mites.

\section{Methods}

\section{Identification of plant samples}

Some samples of plant species, such as mulberry (Morus alba L.), sweet potato (Ipomoea batatas (L.) Lam) and castor bean (Ricinus communis L.), were identified by Flora and Phytotaxonomy Research Department, Horticultural Research Institute, Agricultural Research Center.

\section{Biological studies}

Laboratory studies were carried out to study the effect of different host plants on biology of Tetranychus urticae under controlled temperature $\left(28.5 \pm 2{ }^{\circ} \mathrm{C}\right)$ and relative humidity $(76 \pm 5 \%)$. Thirteen newly emerged females were transferred with adult males in couples from a culture maintained at Sakha laboratory by camel brush on 13 discs of each of sweet potato, mulberry, and castor bean; each disc is $4 \mathrm{~cm}$ in diameter. Thirteen emerged larvae of the same age were confined to leaf discs. Each leaf disc was put upon a wet cotton pad in a petri dish (15 $\mathrm{cm}$ in diameter). Mite individuals were allowed to develop, and females were left to deposit eggs. The experiment was examined twice daily, and plant leaf discs were replaced by fresh ones when necessary. All development periods for all stages of Tetranychus urticae, hatchability percentage, and sex ratio were recorded.

\section{Estimation of some leaf contents}

Nitrogen (\%) in the leaves was estimated following the micro-Kjeldhal method as outlined by Jackson (1973). Phosphorous (\%) was estimated according to Jackson (1973). The concentration of potassium (\%) in leaf extract was determined by flame photometric method Jackson (1973). The total chlorophyll content (mg/g) was determined using dimethyl sulfoxide (DMSO) method given by Shoef and Lium (1976) and Lichtenthaler (1987).

\section{Statistically analysis}

Obtained data were analyzed using ANOVA and then $F$ test. Significant differences among means were compared using Duncan (1955) multiple test at 5\% level in different treatments. Also, simple correlation according to Snedecor and Cochran (1967) was calculated using Minitab (2007).

\section{Results}

Data in (Table 1) showed the influence of host plants on developmental stages of Tetranychus urticae females. The hosts affected significantly on incubation period. The least incubation period was on castor bean leaves $(2.5+0.54$ days). The larval period was shortest $(1.64 \pm 0.23$ day) when rearing on castor bean. Results revealed significant differences among sweet potato, mulberry, and caster bean leaves in protonymph stage, dueto-nymph stage, and total immature

Table 1 Impact of different host plants on development durations of immature Stages of Tetranychus urticae females

\begin{tabular}{|c|c|c|c|c|c|}
\hline Host & Incubation period (day) & Larval period (day) & Proto-nymph period (day) & Deuto-nymph period (day) & Total immature stages (day) \\
\hline Sweet potato & $2.88 \pm 0.52^{b}$ & $.2 .52 \pm 0.35^{a}$ & $3.16 \pm 0.39^{a}$ & $4.72 \pm 0.54^{a}$ & $10.90 \pm 0.67^{a}$ \\
\hline Mulberry & $4.83 \pm 0.60^{a}$ & $1.64 \pm 0.23^{a}$ & $1.65 \pm 0.12^{c}$ & $2.61 \pm 0.23^{b}$ & $5.90 \pm 0.27^{b}$ \\
\hline Castor bean & $2.50 \pm 0.54^{b}$ & $2.88 \pm 0.52^{a}$ & $2.88 \pm 0.13^{b}$ & $3.51 \pm 0.45^{\mathrm{ab}}$ & $9.26 \pm 0.87^{a}$ \\
\hline
\end{tabular}

The different letters indicated significant differences between treatments

The same letters indicated not significant differences between treatments 
Table 2 Influence of different host plants development durations on of Tetranychus urticae females

\begin{tabular}{lllll}
\hline Host & Life cycle period & Generation period & Longevity period & Life span period \\
\hline Sweet potato & $13.78 \pm 1.10^{\mathrm{a}}$ & $14.82 \pm 1.27^{\mathrm{a}}$ & $16.42 \pm 3.09^{\mathrm{a}}$ & $30.19 \pm 2.75^{\mathrm{a}}$ \\
Mulberry & $9.90 \pm 0.87^{\mathrm{c}}$ & $11.90 \pm 0.62^{\mathrm{a}}$ & $15.0 \pm 0.41^{\mathrm{a}}$ & $24.9 \pm 0.83^{\mathrm{ab}}$ \\
Castor bean & $11.76 \pm 0.94^{\mathrm{b}}$ & $13.64 \pm 1.27^{\mathrm{a}}$ & $8.5 \pm 0.73^{\mathrm{b}}$ & $20.26 \pm 1.41^{\mathrm{b}}$ \\
\hline
\end{tabular}

The same letters indicated no significant differences between treatments

The different letters indicated significant differences between treatments

periods where these periods were the shortest when $T$. urticae females were reared on the mulberry leaves and these periods were $(1.64 \pm 0.23$ days $),(1.65 \pm 0.12$ days $)$ and (5.90 \pm 0.27 days), respectively. Results in (Table 2) demonstrated the influence of different host plants on developmental stages of $T$. urticae female. The mite life cycle period varied significantly due to its rearing on different hosts; hence, the life cycle period was shorter on mulberry leaves $(9.90 \pm 0.87$ days). The generation period was $11.9 \pm 0.62$ days when rearing on mulberry leaves at 28.5 $\pm 2{ }^{\circ} \mathrm{C}$ and $76 \pm 5 \%$ relative humidity. No significant differences in generation period of T. urticae were found when the mite was fed on sweet potato, mulberry, or castor been leaves. Data revealed significant differences among different host plants leaves for longevity and life span periods as these periods were shortest when $T$. urticae was fed on castor bean leaves. Data in Fig. 1 demonstrated the effect of different host plants on the biology and reproduction rate of $T$. urticae females, no significant differences were found in average numbers of egg per day when T. urticae was reared on sweet potato, mulberry, and castor bean leaves; however, the average was higher when the mite was bred on castor bean leaves $(4.45 \pm 0.38$ eggs/day). No significant differences in reproduction rate per female were found

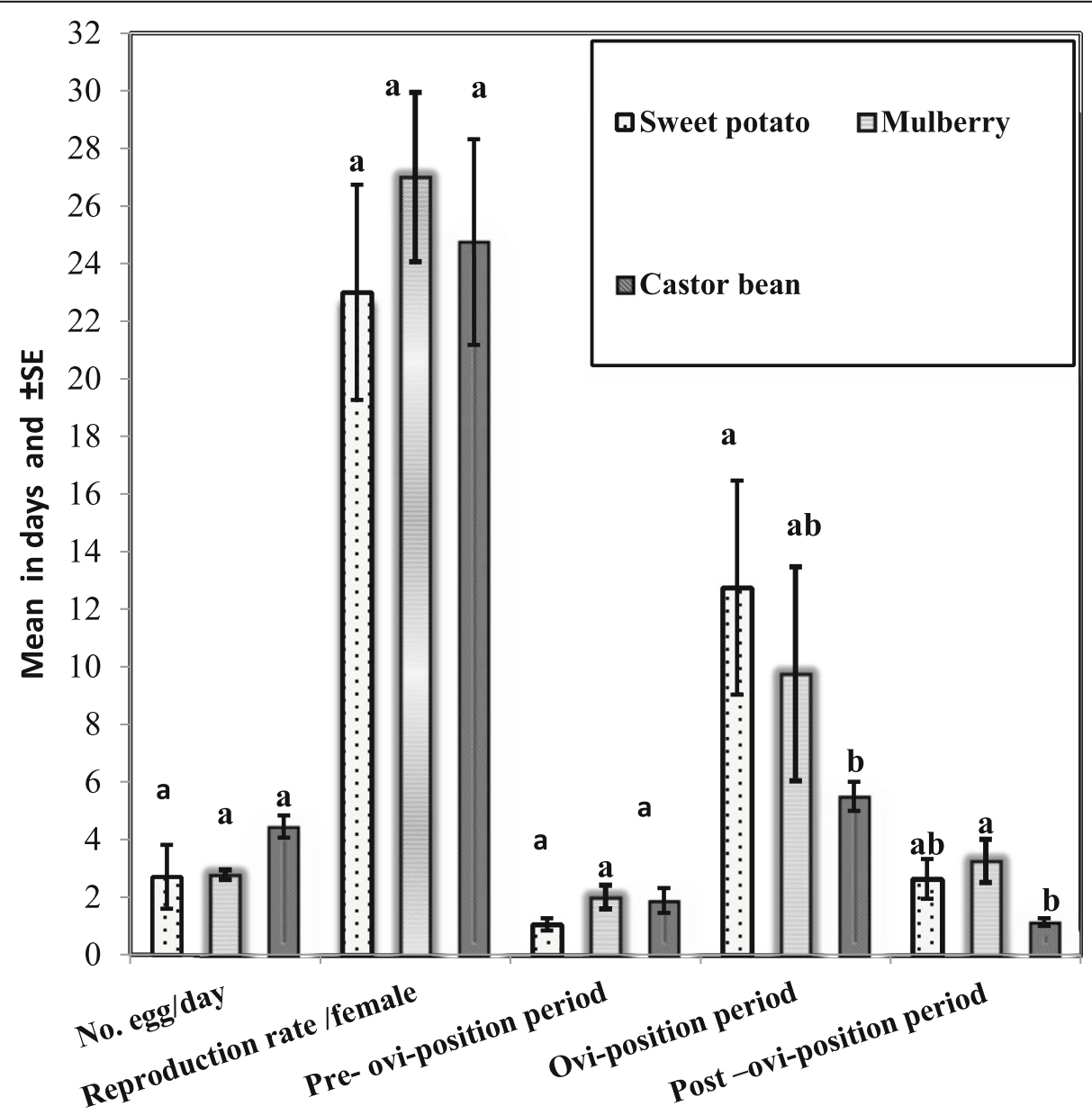

Fig. 1 Effect of different host plants on the biology and reproduction rate of Tetranychus urticae females 
when it was reared on sweet potato, mulberry, and castor bean leaves. Pre-oviposition periods did not differ significantly when mite was reared on any of the three host plants, but significant differences were found in postoviposition period when it was reared on mulberry and castor bean leaves. Oviposition period was significantly higher on sweet potato than on castor bean but did not differ significantly between mulberry and each of sweet potato and castor bean. Results in Fig. 2 revealed influence of different host plants on hatchability and sex ratio of $T$. urticae female. Egg hatchability differed among the host plants, as it was the highest $(96.30 \pm 0.01)$ on mulberry, followed by sweet potato $(94.57 \pm 0.03 \%)$, and castor bean (87.88 \pm 0.07 ). The sex ratio was the highest when $T$. urticae was reared on castor bean $(86.67 \%)$, but the sex ratio for male was the highest $(40.14 \%)$ when $T$. urticae breed on sweet potato leaves. Data in Fig. 3 exhibited significant differences between sweet potato, mulberry, and castor bean leaves in incubation and larval periods when male of $T$. urticae reared on these plants, where values of incubation period were $1.25 \pm 0.25$ days, $1.88 \pm 0.9$ days, and $3.25 \pm 0.14$ days, respectively. While values of larval period were $2.90 \pm$ 0.50 days, $1.68 \pm 0.24$ days, and $1.25 \pm 0.14$ days, respectively. Total immature periods was $5.01 \pm 0.18$ days less when $T$. urticae was fed on castor bean leaves, while longevity period was $4.15 \pm 0.50$ days less when $T$. urticae was fed on sweet potato than other host plants. Life span period was short $(12.90 \pm 1.04$ days $)$ when T. urticae was reared on castor been.

\section{Some leaf contents in host plants}

Nitrogen content in plant leaves varied (Fig. 4), with highest value in castor bean, and lowest value in mulberry. Also, differences in concentrations of potassium, phosphorus, and total chlorophyll were found between three host plants; hence, mulberry leaves had less phosphorus and total chlorophyll content, while castor bean leaves had highest total chlorophyll $(2.67 \pm 0.01 \mathrm{mg} / \mathrm{g})$ (Fig. 5) and potassium content $(1.52 \% \pm 0.01)$.

\section{Correlation between biological aspects of Tetranychus urticae Koch and host leaf contents}

Results in Table 3 revealed that the duration of total immature stages correlated insignificantly positive with nitrogen and potassium leaf contents whatever the host plant. In case of phosphorus and total chlorophyll contents, the correlations were negatively insignificant in the hosts sweet potato and mulberry but insignificantly positive with castor bean. The life cycle period correlated insignificantly positive with all considered leaf contents, with the exception of phosphorus and total chlorophyll contents of sweet potato that was insignificantly negative. However, the correlation between the duration spider mite life cycle and nitrogen content was significantly positive in case castor bean. Generation period correlated insignificantly positive with all leaf contents in three host plants with the exception of potassium and total chlorophyll contents in the case of sweet potato, which were insignificantly negative. Longevity period had insignificantly negative with all considered

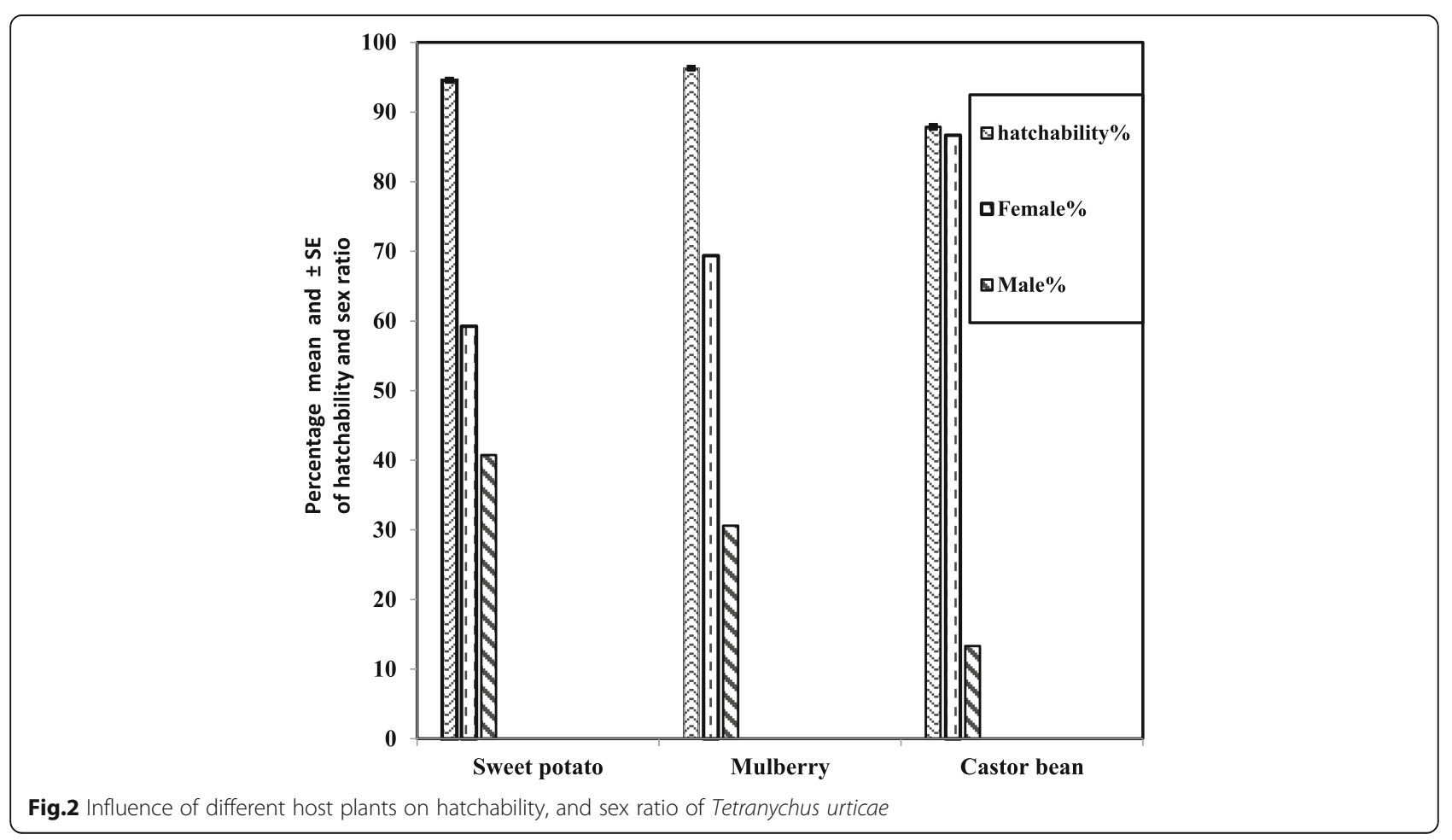




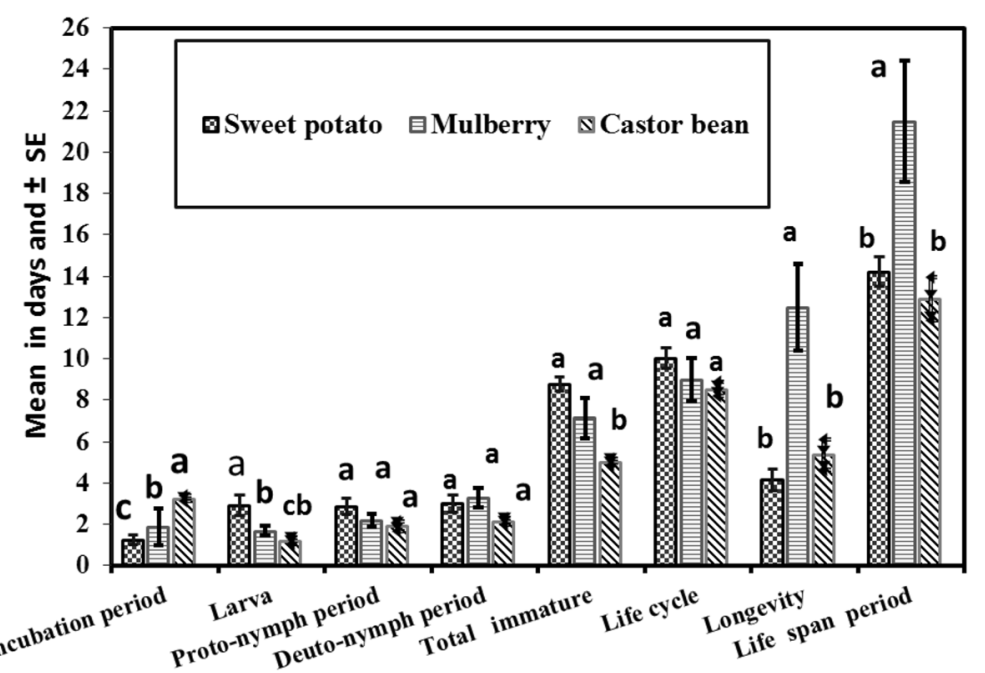

Fig.3 Effect different food types on biological aspects of Tetranychus urticae males

contents but with some exceptions. However, the correlation between longevity period with nitrogen and potassium contents were highly significantly positive and insignificantly positive, respectively, in the case of sweet potato. In the case of castor bean, the correlations between longevity period and each of phosphorus and potassium were insignificantly positive and significantly positive, respectively (Table 3). As for the life span period, in sweet potato, the correlations were insignificantly positive with potassium. In mulberry, the correlations were insignificantly negative with each of nitrogen and total chlorophyll but insignificantly positive with each of phosphorus and potassium contents. However, in castor bean, the correlations between life span duration and each of phosphorus and potassium and total chlorophyll were always insignificantly positive (Table 3).

\section{Discussion}

The obtained results for generation period of $T$. urticae when it was feed on mulberry leaves were in disagreement with those obtained by Sakunwarin, Chandrapatya, and Baker (2003) who found that T. truncatus females completed the generation in 17.4 days when reared on mulberry leaves at $20{ }^{\circ} \mathrm{C}$ and 8.1 days when reared at $35{ }^{\circ} \mathrm{C}$ and the fecundity ranged from 40 to 66 eggs at temperature from 3 to $31{ }^{\circ} \mathrm{C}$. Results indicated that the reproduction rate per female was $27 \pm 2.94$ eggs on mulberry leaves at $\left(28.5 \pm 2{ }^{\circ} \mathrm{C}\right)$. The obtained results for egg stage and total immature stages of $T$. urticae female when reared on caster bean leaves were different from those obtained by Imani and Shishehbor (2009) who found that Eutetranychus orientalis female reared on caster bean leaves took at average of 12.4 days at $30{ }^{\circ} \mathrm{C}$

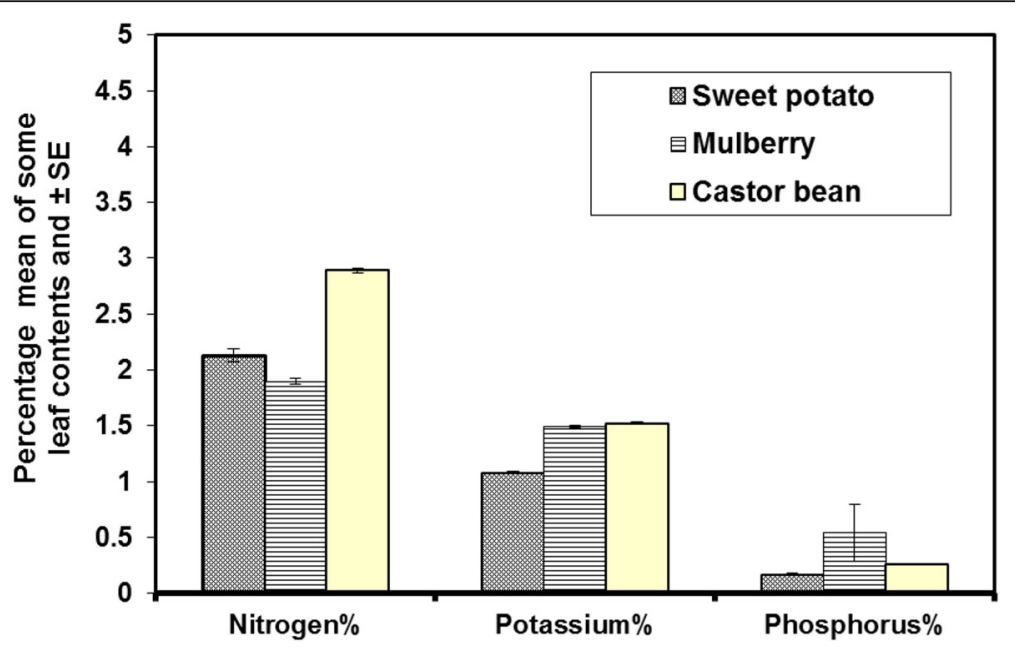

Fig.4 Some leaf contents of nitrogen, phosphorus, and potassium in the three host plant leaves 


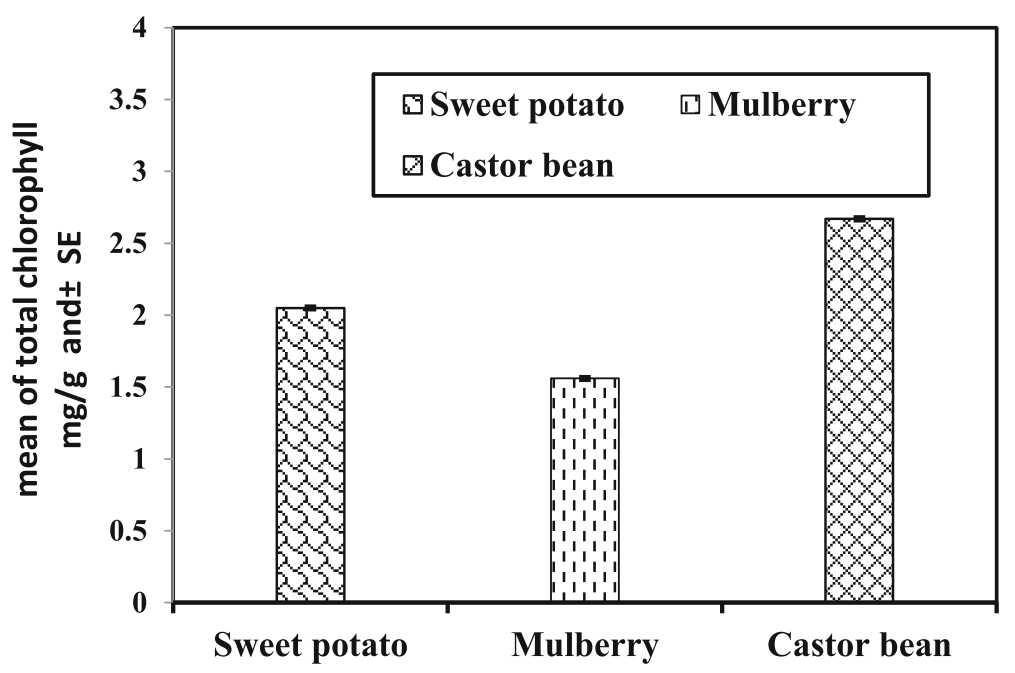

Fig.5 Total chlorophyll in three host plants leaves

and 22.3 days at $20{ }^{\circ} \mathrm{C}$ to develop from egg to adult. The obtained results for reproductive rate per female of $T$. urticae when reared on sweet potato leaves are in agreement with those obtained by Zaher and Shehata (1965) who found that the reproductive rate or fecundity per female was 20-40 eggs when Oligonychus magnifiers (R. and S) (A carina: Tetranychidae) reared on sweet potato leaves.

The results are similar to those obtained by Biswas et al. (2004) who reported that the duration of protonymph and deuto-nymph stages of T. urticae were 3.0 and 3.5 days, respectively, when reared on eggplant. The obtained results for periods of total immature and generation of T. urticae female when reared on caster bean leaves are in accordance with those obtained by Hoda, Taha, Sawires, and Ahmed (1990) who found that period of total immature was $9.28 \pm 0.68$ when $T$. arabicus was reared on oil crop as colza rape. However, when it was reared on safflower, the generation period was (13.98 \pm 0.30 ). The obtained results of the relationship between each period of those life cycle, period, longevity period,

Table 3 Relationship between developmental stages of Tetranychus urticae female with nitrogen, phosphorus, potassium, and total chlorophyll in different host plants

\begin{tabular}{|c|c|c|c|c|c|}
\hline Host & Biological aspects & $N(r)$ & $P(r)$ & $\mathrm{K}(r)$ & Total chlorophyll \\
\hline Sweet potato & Total immature stages & 0.380 & -0.153 & 0.449 & -0.281 \\
\hline Mulberry & & 0.599 & -0.348 & 0.871 & -0.021 \\
\hline Castor bean & & 0.058 & 0.679 & 0.683 & 0.065 \\
\hline Sweet potato & Life cycle period & 0.198 & -0.388 & 0.506 & -0.391 \\
\hline Mulberry & & 0.033 & 0.223 & 0.590 & 0.081 \\
\hline Castor bean & & $0.960^{*}$ & 0.264 & 0.286 & 0.612 \\
\hline Sweet potato & Generation period & 0.230 & -0.449 & 0.589 & -0.476 \\
\hline Mulberry & & 0.239 & 0.051 & 0.877 & 0.076 \\
\hline Castor bean & & 0.814 & 0.410 & 0.436 & 0.527 \\
\hline Sweet potato & Longevity period & $0.722^{* *}$ & -0.597 & 0.164 & -0.373 \\
\hline Mulberry & & -0.666 & -0.741 & -0.362 & -0.898 \\
\hline Castor bean & & -0.491 & 0.980 & $0.960^{*}$ & -0.439 \\
\hline Sweet potato & Life span period & $-0.569^{*}$ & -0.825 & 0.386 & -0.575 \\
\hline Mulberry & & -0.614 & 0.131 & 0.438 & -0.357 \\
\hline Castor bean & & 0.762 & 0.980 & 0.699 & 0.177 \\
\hline
\end{tabular}

$r=$ correlation

*Significant at level (5\%)

**High significant at level (1\%) 
life span, and nitrogen are in accordance with those obtained by Hoffland, Dicke, Tintelen, Dijk man, and Vam Beusichem (2000) and Chow, Chau, and Heinz (2009)) who found that nitrogen has an impact on biology of $T$. urticae.

The obtained results from the present differences between the three host plants in development periods, reproduction rate, and some leaves' content when $T$. urticae was feed on leaves for these plants were in agreement with Wermelinger, Oertli, and Baumgarmer (1991) and Rasmjou, Tavakkoli, and Nemati (2009); they found that development periods, reproduction, and survivor of T. urticae are influenced by characteristics of host plant such as nutritional quality.

During the experiment, appearance mortality to some development stages when $T$. urticae was reared on castor bean, sweet potato, and mulberry was observed and these results are in accordance with Motaheri, Katayoon, Rostaee, and Talebi (2014) who observed the mortality of immature stages of $T$. urticae increased with higher nitrogen concentrations when it was reared on cucumber leaves nourished by four levels of nitrogen.

\section{Conclusions}

From biological studies, it is concluded that the shortest durations of incubation, life span, longevity, and oviposition periods were recorded when $T$. urticae was reared on castor bean leaves, while total immature stages and life cycle were shortest when spider mite was fed on mulberry leaves. The greatest values of reproduction rate and hatchability were found on mulberry leaves than other crops and followed by castor bean. Sex ratio of T. urticae was highest on castor bean leaves. The developmental and reproduction rate of $T$. urticae are influenced by species of host plant and tissue nutrient content for host plant.

\section{Abbreviations}

$( \pm$ SE): Positive or negative Standard error; (T. urticae): Tetranychus urticae

\section{Acknowledgements}

The author is indebted to Prof. Dr. Ramzy Sherif (Plant Protection Research Institute, Agricultural Research Center) who revised the draft of the manuscript, and deep thanks and gratitude to Prof. Dr. Abd El-Halim Mohammed who identified some samples of plant species, Horticultural Research Institute, Agricultural Research Center.

\section{Funding}

The study is self-financed.

\section{Availability data and materials} Applicable.

\section{Author's contributions}

The author read and approved the final manuscript.

\section{Authors' information}

Name: Malakah farrag Ibrahim Ahmed Elsadany

Institute: Plant Protection Research Institute, Sakha Agricultural Research

Station, Kafr El-Sheikh, Agricultural Research Center, Giza, Egypt

Department: Acarology of Cotton and Crops
Station: Sakha Agricultural Research Station

E-mail: malkahelsadany@gmail.com

Specialty: Zoology (Acarology)

Occupation: Researcher

Ph.D.

Specialty: Zoology (Ecology)

College: Faculty of Science

University: Tanta University

M.Sc.

Specialty: Zoology (Invertebrates)

College: Faculty of Science

University: Al-Azhar University (Girls Branch)

\section{Competing interests}

This work would add value to earlier work by other researches but dealing with other utilizing similar plant species in addition to other plant species.

\section{Publisher's Note}

Springer Nature remains neutral with regard to jurisdictional claims in published maps and institutional affiliations.

Received: 7 August 2017 Accepted: 16 February 2018

Published online: 13 March 2018

\section{References}

Biswas, G. C., Islam, W., Haque, M. M., Saha, R., Haque, K. K. M. F., Islam, M. S., \& Haque, M. E. (2004). Some biological aspects of carmine spider mite, Tetranychus cinnabarinus Boisd, ( Acari : Tetranychidae) infesting eggplant from Rajshahi. Journal of Biological Sciences, 4(5), 588-591.

Bolland, H. R., Gutierrez, J., \& Freshman, C. H. W. (1998). World catalogue of the spider mite family (Acari: Tetranychidae). Leiden: Koninklijke Brillniv 408 pp.

Chow, A., Chau, A., \& Heinz, K. M. (2009). Reducing fertilization for cut roses: Effect on crop productivity and two spotted spider mite abundance, distribution, and management. J. Econ. Entomol, 102(5), 1896-1907.

Duncan, B. D. (1955). Multiple range and multiple F test. Biometrics, 11, 1-14.

Fasulo, T. R. (2009). Common name: Two spotted spider mite, scientific name: Tetranychus urticae Koch (Arachnida: Acari: Tetranychidae). In J. L. Gillett-Kaufma (Ed.), Featured creatures, Entomology \& Nematology. University of Florida, DPI Entomology Circular. http://edis.fas.ufl.edu/in307.

Hoda, F. M., Taha, M. A., Sawires, Z. R., \& Ahmed, M. A. (1990). Effect of different host plants on the development and fecundity of the spider mite, Tetranychus arabicus Attiah. Agric Res, Review, 68, 11-15.

Hoffland, E., Dicke, M., Tintelen, W. V., Dijk man, H., \& Vam Beusichem, M. L. (2000). Nitrogen availability and defense of tomato against two spotted spider mite. J. Chemistry and Ecology, 26(12), 2697-2711.

Imani, Z., \& Shishehbor, P. (2009). Effect of temperature on life history and life tables of Eutetranychus orientalis (Klein) (Acari: Tetranychidae). Systematic and Applied Acarology, 14, 11-18.

Jackson, M. L. (1973). Soil chemical analysis. Bombay: Oxford and IBH publishers,

Lichtenthaler, H. K. (1987). Chlorophylls and carotenoids: Pigments of photosynthetic membranes. Method Enzymology., 148, 350-382.

Migeon, A., \& Dorkeld, F. (2013). Spider mite web : a comprehensive data base for Tetranychidae. http://www1.montpellier.inra.fr/cbgp/spmweb/. http:// www.diva-gis.org.

Minitab, (2007). Statistical software program. Version 15, Minitab Inc.

Motaheri, M., Katayoon, K., Rostaee, A. M., \& Talebi, A. A. (2014). The impact of cucumber nitrogen nutrition on life history trait of Tetranychus urticae Koch (Acari: Tetranychidae). Acarologia, 54(4), 443-452.

NAPPO (2014). Morphological identification of spider mites (Tetranychidae) affecting important fruits. North American Plant Protection Organization pp. 30.

Rasmjou, J., Tavakkoli, H., \& Nemati, M. (2009). Life history traits of Tetranychus urticae Koch on three legumes (Acari: Tetranychide ). Munis Entomology and Zoology, 4(1), 204-211.

Rinehold, J., Bell, N., \& Waters, T. (2015). Vegetable crops, vegetable pests. In Insect hand book, (pp. 1-20).

Sakunwarin, S., Chandrapatya, A., \& Baker, G. T. (2003). Biology and life table of the cassava mite, Tetranychus truncatus Ehara (Acari: Tetranychidae). Systematic and Applied Acarology., 8, 13-24.

Shoef, T. W., \& Lium, B. W. (1976). Improved extraction of chlorophyll a, and $b$ from algae using dimethyl sulfide. Limnology and Oceanography, 21(6), 926-928. 
Snedecor, G. W., \& Cochran, W.G. (1967). Statistical methods 6th Ed . Lowa State Univ. press, Ames, Iwa, USA, 325-330.

Wermelinger, B., Oertli, J. J., \& Baumgarmer, J. (1991). Environmental factors affecting the life tables of Tetranychus urticae (Acari: Tetranychidae ), III. Host plant nutrition. Experiment Applied Acarology, 12, 259-274.

Zaher, M.A. and Shehata, K.K. (1965) Oligonychus vitis n. sp. (Acarina:

Tetranychidae), Bulletin de la Societe Entomologique d'Egypte, 49, 67-69.

\section{Submit your manuscript to a SpringerOpen ${ }^{\bullet}$ journal and benefit from:}

- Convenient online submission

Rigorous peer review

- Open access: articles freely available online

- High visibility within the field

- Retaining the copyright to your article

Submit your next manuscript at $\gg$ springeropen.com 